\title{
Adolescent gynaecology problems in rural South India: a review of hospital admission in a tertiary care teaching hospital in Ammapettai, Tamil Nadu, India
}

\author{
Wills G. Sheela*, M. Chellatamizh, M. Mohanamba, P. Vijayalakshmi
}

Department of Obstetrics and Gynecology, SSSMC and RI, Ammapettai, Kancheepuram District, Tamil Nadu, India

Received: 21 December 2017

Accepted: 27 March 2017

*Correspondence:

Dr. Wills G. Sheela,

E-mail: drgwillssheelaa@yahoo.in

Copyright: ( $)$ the author(s), publisher and licensee Medip Academy. This is an open-access article distributed under the terms of the Creative Commons Attribution Non-Commercial License, which permits unrestricted non-commercial use, distribution, and reproduction in any medium, provided the original work is properly cited.

\section{ABSTRACT}

Background: Adolescent girl's knowledge about sexual abuse and awareness of health services is poor. The study is conducted to analyse the gynaecological problems mandating hospitalization and to formulate modalities to improve their health and to ensure safe motherhood. The objectives of this study were to evaluate gynaecological problems in adolescent girls, and to analyse gynaecological emergencies, and to develop modalities to improve adolescent health and for safe motherhood.

Methods: Retrospective hospital based observational study of hospital records regarding health issues and awareness of health services among girls in the age group of 13-19 years hospitalized for various medical and surgical problems during the period of January 2015 to January 2016 at Shri Sathya Sai medical college and Research Institute, Ammapettai, Kancheepuram, Tamil Nadu, India. 50 age, education, social background, knowledge of available health services, contraception and detailed history of menstruation regarding duration, quantity and previous medication prior to admission and their present cause of admission were analysed.

Results: Total admission in the year were 50, medical 34 (including 5 girls who had check curettage for postabortal bleeding with severe anemia) and surgical 16. Early adolescent group were $34(68 \%)$ and late adolescent group were $16(32 \%)$, married were $5(10 \%)$ and unmarried $45(90 \%)$. All 50 girls were from low socioeconomic class, with rural background. $84 \%$ were school dropout and $40 \%$ were unemployed. $20 \%$ of our study subjects were admitted with unsafe abortion with postabortal bleeding with no knowledge about Health services.16\% were sexually abused and were raped. Abnormal uterine bleeding(menorrhagia) is the most common gynaecological problem in adolescent girls in our study. DUB (52\%) is the most common cause. Second most common cause for abnormal bleeding is postabortal bleeding (40\%). The most common surgical procedure done was check curettage for postabortal bleeding in $10 \%$. Next common surgery was laparotomy for ovarian cyst in $6 \%$ cases and for torsion adnexal cyst in $6 \%$.

Conclusions: The most important cause for admission was anemia following abnormal excessive bleeding P/V due to DUB or postabortal bleeding. Second most important cause was ovarian tumours. Unprotected coitus, sex abuse and repeated unsafe abortions have increased the rate of PID and ectopic pregnancies. The study emphasizes the need to sensitize these young girls on the issue like excessive menstruation, gender relationships, and sex abuses. Create awareness and promote knowledge regarding medical issue, available health services and contraception to prevent unsafe abortion and its sequelae. Active implementation of projects like ARSH - adolescent friendly reproductive services, where confidentiality is maintained and proper counseling regarding contraception and supplementation of iron and folic acid is given to all adolescent girls who are future mothers and to ensure safe motherhood.

Keywords: Adolescent girls, DUB, Post abortal bleeding, Torsion ovarian cyst 


\section{INTRODUCTION}

Adolescence is the transitional period of life characterized by physical and psychological changes. The word adolescence is derived from a latin word "Adolescere" which means grow into maturity. WHO defines adolescent as individuals in the age group of 1019 years. ${ }^{1}$ Adolescence stretches for between 10-19 years. Early adolescence comprises 10-14 years where physical changes take place and body transformation occurs. Late adolescence encompasses the age 15-19 years. ${ }^{2}$ The sociodemographic characteristics and problems vary from countries, states and places. These physical, psychological and emotional changes are mediated through a complex neuroendocrinal mechanism. The nature of the various problems was unique and specific that they are secretive and share their needs with peers. These girls are susceptible to exogenous and endogenous influences. $^{3}$

Prevalence of anemia associated with menorrhagia were $30 \%$ in girls needing hospital admission for blood transfusion.Most of these girls did not address this issue of excessive menstrual blood loss for fear of disease and embarrassment about discussing menstruation led to delayed presentation with severe anemia. ${ }^{4}$ Pregnancy in teenagers is a problem threatening the ultimate reproductive and child health. These girls often do not have safe sex and are vulnerable to sexually transmitted diseases. Moreover, after getting pregnant, to avoid social problems, they go to quacks and undergo criminal abortion in unauthorized locations and land up with serious complications and chronic pelvic inflammatory disease which affect their reproductive health in future. ${ }^{5}$ Half of the Indian population is below 25 years. $32 \%$ are in 10-20 years. About $20 \%$ adolescent girls were abused by force mostly by known persons. Girls did not report this for fear of shame and social ostracization and threat by the persons who assaulted her. Pregnancy out of marriage is a social stigma in our country which cause lot of psychological and physiological trauma to the girls. A great concern now is the increasing rate of unsafe abortions and complications because of increased opportunities and environment for gender relationship, sexual intimacy and sex abuse. $20 \%$ girls were unmarried and less than 16 years, $40 \%$ were between 17 -19 years reported with pregnancy. $60 \%$ girls were school dropouts with primary education. ${ }^{6}$ Ovarian torsion is a rare gynecological emergency in children which requires an early surgical intervention to save the ovary from necrosis. Ovarian torsion occurs in all age groups. However, it is most commonly seen in adolescent girl, mainly during the post-ovulatory period in many cases. ${ }^{7}$ Knowledge about available health service and contraception was very less as $20 \%$ parents had only primary school education and $73 \%$ were unskilled workers. ${ }^{8}$ These girl's knowledge about sexual abuse and awareness of health services is poor. The study is conducted to analyse the gynaecological problems mandating hospitalization and to formulate modalities to improve health and safe motherhood. Active implementation of "ARSH" Adolescent friendly reproduction and health services initiated by Government of India which includes counselling about common concerns, nutritional needs and confidentiality in addressing issues following sexual abuse and unsafe abortions and direct them for quality abortion services, supplementation of iron and folic acid to all adolescent girls to improve anaemia and provide good health and safe motherhood.

\section{METHODS}

Retrospective hospital based observational study of hospital records regarding health issues and awareness of health services among girls in the age group of 13-19 years hospitalized for various medical and surgical problems during the period of January 2015 to January 2016 at Shri Sathya Sai medical college and Research Institute, Ammapettai, Kancheepuram, Tamil Nadu, India. Age, education, social background, knowledge of available health services, contraception and detailed history of menstruation regarding duration, quantity and previous medication prior to admission and their present cause of admission were studied.

\section{RESULTS}

Table 1 shows age and marital status of the girls. Total admission in the year were 50, medical 34 (including 5 girls who had check curettage for postabortal bleeding with severe anemia) and surgical 16. Early adolescent group were 34 (68\%)and late adolescent group were 16 (32\%), married were $5(10 \%)$ and unmarried $45(90 \%)$. Table 2 shows the cause for medical admission. Abnormal uterine bleeding (menorrhagia) $-50 \%$ is the most common cause for hospitalisation in these girls. DUB $(52 \%)$ is the most common cause for menorrhagia. Next most common cause is postabortal bleeding.

Table 1: Age and marital status of the girls.

\begin{tabular}{|lll|}
\hline Early adolescence (13-15 years) & N & $\%$ \\
\hline Late adolescence (16-19 years) & 16 & $68 \%$ \\
\hline Youngest (13 years) & 1 & $32 \%$ \\
\hline Oldest (19 years) & 1 & - \\
\hline Unmarried & 45 & $90 \%$ \\
\hline Married & 5 & $10 \%$ \\
\hline
\end{tabular}

Table 3 shows elective surgeries. Elective surgical procedures were done in 9 girls -3 girls who presented with primary amenorrhoea with imperforate hymen had hymenectomy, 2 girls who presented with lower abdominal pain with $4.5 * 6 \mathrm{~cm}$ ovarian cyst had laparatomy and cystectomy, whose histopathology was simple serous cyst. 1 young girl studying in 8th standard, was referred by her class teacher for abdominal swelling, laparatomy and left salphingo ophorectomy was done and $7.5 \mathrm{~kg}$ benign ovarian tumour was removed with 
hispathology report showing simple serous cystadenoma. Suction evacuation was done in a 19-year-old girl who had missed abortion with bleeding following snake bite. Gartner cyst excision was done for 1 girl. One girl, who came with painful swelling in labia majora was treated for bartholian abscess.

Table 2: Cause for medical admission.

\begin{tabular}{|c|c|c|}
\hline & $\mathbf{N}$ & $\%$ \\
\hline AUB & 25 & $50 \%$ \\
\hline DUB & 13 & $52 \%$ \\
\hline Postabortal bleeding & 10 & $40 \%$ \\
\hline Hypothyroid & 2 & $8 \%$ \\
\hline \multicolumn{3}{|l|}{ Anemia due to AUB $(\mathrm{N}=25)$} \\
\hline $\mathrm{Hb}<4 \mathrm{~g}$ & 9 & \\
\hline $\mathrm{Hb}<7 \mathrm{~g}$ & 16 & \\
\hline UTI with $E$. Coli $(10 \%)$ & 5 & $10 \%$ \\
\hline Acute PID with dysmenorrhea $(8 \%)$ & 4 & $8 \%$ \\
\hline
\end{tabular}

Table 3: Elective surgeries.

\begin{tabular}{|lll|}
\hline Hymenectomy & N & $\%$ \\
\hline Gartner cyst excision & 3 & $6 \%$ \\
\hline Ovarian cystectomy & 1 & $2 \%$ \\
\hline Left salphingo ophorectomy & 2 & $4 \%$ \\
\hline $\begin{array}{l}\text { Suction evacuation for missed abortion } \\
\text { (snake bite) }\end{array}$ & 1 & $2 \%$ \\
\hline $\begin{array}{l}\text { Bartholin abscess (I and D with } \\
\text { marsupilization) }\end{array}$ & 1 & $2 \%$ \\
\hline
\end{tabular}

Table 4: Emergency surgeries.

\begin{tabular}{|lll|}
\hline Appendectomy & N & $\%$ \\
\hline Torsion dermoid cyst & 2 & $4 \%$ \\
\hline Torsion para ovarion cyst & 2 & $4 \%$ \\
\hline Ruptured tubal pregnancy & 1 & $2 \%$ \\
\hline $\begin{array}{l}\text { Ruptured corpus luteal cyst with } \\
\text { anamalous uterus }\end{array}$ & 1 & $2 \%$ \\
\hline Postabortal bleeding check curettage & 1 & $2 \%$ \\
\hline
\end{tabular}

Table 4 shows emergency surgeries. Two girls who presented with acute abdomen, appendicectomy was done. Laparotomy was done for torsion dermoid cyst in 2 girls and functional cyst torsion in 1 girl. A 16-year-old school girl who presented with acute abdomen had intra operative finding as ruptured corpus luteal cyst with an anomalous uterus. 19 year married girl was operated for ruptures tubal pregnancy. Emergency check curettage was done for 5 girls who presented with postabortal bleeding. Table 5 shows sociodemographic characteristics of girls admitted. All 50 girls were from low socioeconomic class, with rural background. $84 \%$ were school dropout and $40 \%$ were unemployed. $20 \%$ of our study subjects were admitted with unsafe abortion with postabortal bleeding with no knowledge about health services. $16 \%$ were sexually abused and were raped.

Table 5: Sociodemographic characteristics of girls.

\begin{tabular}{|lll|}
\hline Rural background & N & $\%$ \\
\hline Low socioeconomic status & 50 & $100 \%$ \\
\hline Knowledge about health services & 50 & $100 \%$ \\
\hline H/o sexual abuse & 10 & $20 \%$ \\
\hline Employment & 8 & $16 \%$ \\
\hline Unemployed & 20 & \\
\hline Sales girl & 9 & $18 \%$ \\
\hline House maid & 5 & $10 \%$ \\
\hline Construction workers & 16 & $32 \%$ \\
\hline Education & \multicolumn{2}{|c|}{} \\
\hline School dropouts & 42 & \\
\hline Upto $5^{\text {th }}$ std. & 18 & \\
\hline Upto $8^{\text {th }}$ std. & 24 & $84 \%$ \\
\hline Upto $10^{\text {th }}$ std. & 3 \\
\hline Upto $12^{\text {th }}$ std. & 5 \\
\hline
\end{tabular}

\section{DISCUSSION}

The present study shows that abnormal uterine bleeding(menorrhagia) is the most common gynaecological problem in adolescent girls. Abnormal uterine bleeding observed in this study were in the form of DUB 13, postabortal bleeding 10, menorrhagia due to hypothyroidism 2. DUB $(52 \%)$ is the most common cause of menorrhagia in our study. Second most common cause is postabortal bleeding $40 \%$. This is more consistent with Jagnnath $\mathrm{P}$ et al study in which menorrhagia was the commonest cause of admission and DUB (67.5\%) was the most common.The study by Ramaraju HE et al also showed $59.45 \%$ cases of menstrual irregularities were due to DUB. ${ }^{1,2}$

Out of 50 girls, $25(50 \%)$ were anemic in our study, 9 were with haemoglobin less than 4 gms and 16 were less than 7 gms. All needed packed cell transfusion. In the study conducted by Bhalerao-Gandhi A et al $26 \%$ of the girls had severe anemia. ${ }^{3}$ Sebanthi $G$ et al has reported $60 \%$ of the study subject had anemia with $\mathrm{Hb}$ less than 8 gms who needed blood transfusion. ${ }^{5} 3$ girls with $\mathrm{Hb}$ less than 4 gms needed packed cell transfusion. Menorrhagia due to hypothyroidism in our study was seen in 4 cases. Study by Bhalerao-Gandhi A et al found hypothyroidism as the cause of menorrhagia in 2 cases. ${ }^{3}$ Kumari A study had hypothyroidism in 3 cases. ${ }^{4}$ This finding is consistent with our study. In our study 4 cases had PID with dysmenorrhea. This is similar to study done by Goswami $\mathrm{S}$ et al - dysmenorrhea was seen in 5 cases. ${ }^{5}$ Postabortal bleeding with anemia was seen in 10 girls $(20 \%)$ in our study. All gave H/o medical abortion and they all needed blood transfusion. ${ }^{5}$ Girls had emergency check curettage. Similar scenario has been reported by Nkyekyer K, where $46 \%$ of his unmarried subjects were treated for postabortal bleeding with anemia. ${ }^{6} \mathrm{He}$ has also reported 
$30 \%$ girls were treated for vaginal tears and haemorrhage following rape. In our study 5 cases $(10 \%)$ had UTI with E. Coli. In the study by Nkyekyer K, $13 \%$ girls had urinary infection, $19 \%$ had PID due to repeated unsafe abortion. $^{6}$

In our study, the most common surgical procedure done was check curettage for postabortal bleeding in $10 \%$. Next common surgery was laparotomy for ovarian cyst in $6 \%$ cases and for torsion adnexal cyst in 6\%. In Kumari A study ovarian tumour was seen in $4.5 \% .{ }^{4}$ Emergency laparotomy for torsion dermoid cyst in young girls was reported by Acimi S. ${ }^{7}$ Adnexal torsion is reported by Zolton JR in $3 \%$ of young girls The most common histology in our study is simple serous cystadenoma $(50 \%)$ followed by dermoid cyst $(30 \%) .{ }^{8}$ Chaopotong P et al has reported $91 \%$ of the tumours were germ cell and $1 \%$ dysgerminoma. ${ }^{9}$ In our study ruptured tubal pregnancy is seen in $2 \%$ and ruptured corpus luteal cyst in $2 \%$. Ruptured ectopic pregnancy was reported by Nkyekyer $\mathrm{K}$, in $43.3 \%$ patients and in $8 \%$ cases by Wamwana EB et al. 6,10

\section{CONCLUSION}

50 girls admitted in the hospital were analysed. 34 were medical causes of which the most important cause for admission was anemia following abnormal excessive bleeding $\mathrm{P} / \mathrm{V}$ due to DUB or postabortal bleeding. Second most important cause was ovarian tumours. Unprotected coitus, sex abuse and repeated unsafe abortions have increased the rate of PID and ectopic pregnancies.

The study emphasizes the need to sensitize these young girls on the issue like excessive menstruation, gender relationships, and sex abuses. Create awareness and promote knowledge regarding medical issue, available health services and contraception to prevent unsafe abortion and its sequelae. Active implementation of projects like ARSH- adolescent friendly reproductive services, where confidentiality is maintained and proper counseling regarding contraception and supplementation of iron and folic acid is given to all adolescent girls who are future mothers and to ensure safe motherhood.

\section{Funding: No funding sources}

Conflict of interest: None declared

Ethical approval: The study was approved by the Institutional Ethics Committee

\section{REFERENCES}

1. Jagannath P, Prasad DB, Kumar BM. Evaluation of gynaecological problems among adolescent girls attending gynaecology out-patient department in Gauhati medical college and hospital. Sch J App Med Sci. 2015;3(7D):2729-32.

2. Ramaraju HE, Shiva Kumar HC, Khazi AA. Adolescent gynaecological problems in a tertiary care centre. Ind J Bas App Med Res. 2015:4(4):64953.

3. Bhalerao-Gandhi A, Vaidiya R, Bandi F. Managing gynaecological problems in indian adolescent girls- a challenge of 21 st century. Obstet Gynecol Int J. 2015;3(1):70.

4. Kumari A. Adolescent gynaecological problems: a clinical study. J Evolut Med Den Sci. 2013;2(9):1111-5.

5. Sebanti G, Dutta R, Sebani S. A profile of adolescent girls with gynaecological problems: J Obste Gynaecol Ind. 2005;55(4):353-5.

6. Nyekyer K. Major gynaecological surgery in the 'ghanaian adolescent'. East African Med J. 2004;81(8):392-7.

7. Acimi S. Acute ovarian torsion in young girls,. J Acute Dis. 2016;5(1);59-61.

8. Zolton JR, Maseelall PB. Evaluation of ovarian cyst in adolescents. Open J Obstetr Gynaecol. 2013:12-6.

9. Chaopotong P, Therasakvichya S, Leelapatanadit C, Jaishuen A, Kuljarusnont S. Ovarian cancer in children and adolescents:treatment and reproductive overcome. Asian Pacific J Cancer Prevent. 2015;16(11):4784-90.

10. Wa Mwana EB, Ndavi PM, Gichangi PB, Karanja JG, Muia EG, Jaldesa GW. Socio demographic charecteristics of patients admitted with gynaecological emergency conditions at a provincial general hospital Kamega, Kenya. East African Med J. 2006;83:12.

Cite this article as: Sheela WG, Chellatamizh M, Mohanamba M, Vijayalakshmi P. Adolescent gynaecology problems in rural South India: a review of hospital admission in a tertiary care teaching hospital in Ammapettai, Tamil Nadu, India. Int J Reprod Contracept Obstet Gynecol 2017;6:1920-3. 